\title{
Investigation of in situ soil nitrogen mineralization in a Picea-Abies forest on the Tibet Plateau: effects of increased nitrogen input
}

\author{
Wang $\mathrm{Ge}^{1}$, Han Lin ${ }^{2 *}$, Tang Xinying ${ }^{1}$ and Yang $\mathrm{Yu}^{2}$ \\ ${ }^{1}$ Institute of Plateau Meteorology, China Meteorological Administration, Chengdu 610072, China \\ ${ }^{2}$ Chengdu University of Information Technology, Chengdu 610225, China
}

doi: $10.4154 / g c .2019 .27$

Article history:

Manuscript received May 13, 2019 Revised manuscript accepted August 30, 2019 Available online December 20, 2019

\begin{abstract}
The main objective of this study was to quantify the dynamics of ammonium $\left(\mathrm{NH}_{4}{ }^{+}\right)$and nitrate $\left(\mathrm{NO}_{3}{ }^{-}\right)$in the humus $(0-7 \mathrm{~cm})$ and the uppermost mineral layer $(0-15 \mathrm{~cm})$ of a forest soil. The soil was treated annually from 2012 to 2013 with one single dose of nitrogen $\left(0,15,30 \mathrm{~kg} \mathrm{~N} \mathrm{ha}^{-1} \mathrm{yr}^{-1}\right.$ applied as $\left.\left(\mathrm{NH}_{4}\right)_{2} \mathrm{SO}_{4}, \mathrm{NH}_{4} \mathrm{Cl}, \mathrm{KNO}_{3}\right)$. Net $\mathrm{N}$ mineralization, including net ammonification and net nitrification was determined in four in situ incubation periods over 2 years in a Picea-Abies forest stand at the Qinghai-Tibet Plateau, Southwest China. Measurements were done using soil cores $(7 \mathrm{~cm}$ or $15 \mathrm{~cm}$ deep) with a resin bag filled with combined anion and cation exchange resins placed at the base to collect the $\mathrm{N}$ leaching from the soil. The accumulation rate of $\mathrm{N}$ was corrected for both deposition and fertilizer $\mathrm{N}$ inputs. In all treatments, both the content and accumulation of the mineral $\mathrm{N}$ were dominated by $\mathrm{NH}_{4}{ }^{+}$which accounts for about $76-89 \%$ of the net mineralization. The accumulation rate of $\mathrm{N}$ decreased to $64-83 \%$ in $\mathrm{KNO}_{3}$ treatments. The net $\mathrm{N}$ mineralization rate increased with nitrogen input, especially in $\mathrm{NH}_{4}{ }^{+}-\mathrm{N}$ treatments $(p<0.05)$. However, this promoting role decreased over time. At the highest $\left(\mathrm{NH}_{4}\right)_{2} \mathrm{SO}_{4}$ additions, the net ammonification and net mineralization rate increased notably in the humus $(0-7 \mathrm{~cm})$ rather than in the uppermost mineral layer $(0-15 \mathrm{~cm})$. Previous studies that reported on soil net mineralization from forests under different environmental conditions were compiled and assessed for the effects of atmospheric $\mathrm{N}$ deposition and environmental factors, annual precipitation, and annual temperature on annual fluxes of net nitrogen mineralization in forest soils, worldwide. The results show that an increase in atmospheric $\mathrm{N}$ deposition significantly enhances the soil net nitrogen mineralization rate. Variation in atmospheric $\mathrm{N}$ deposition accounts for $48 \%$ of the variation in the rate of soil net nitrogen mineralization across the forests.
\end{abstract}

Keywords: $\mathrm{N}$ deposition, nitrogen mineralization, $\mathrm{N}$ transformation, forest soil, flux
China is the third largest nitrogen deposition concentration area in the world (RICHTER et al., 2005). However, most of the research on atmospheric nitrogen deposition on forest soil nitrogen behaviours is conducted in laboratories (ZHOU \& OUYANG et al., 2001; ZHOU et al., 2003). The dilemma here is that this cannot properly reflect the in-situ soil nitrogen transformation (ARNOLD et al., 2008) unless in-situ studies are conducted. At present, very few in-situ field research activities are underway in China to investigate the effects of atmospheric nitrogen deposition increase on forest soil nitrogen transformation flux. Most of the reported research concerns subtropical/tropical forest ecosystems (MENG et al., 2001; FANG et al., 2004; LI \& SHA 2005; CHEN \& JAN, 2007). Hence, this cannot be considered enough for a comprehensive assessment of the effects of atmospheric nitrogen deposition on net transformation of forest soil nitrogen in different areas in China. Nevertheless, there are many in situ observations reported in the international literature on net transformation fluxes of temperate forest soil nitrogen. To the best of our knowledge, there is a lack of research on comprehensive assessment of the effects of deposition of different forms of nitrogen, different forest types, and different climatic factors on the net mineralization flux of soil nitrogen.

To address this issue, a comprehensive in-situ investigation of the effects of simulated atmospheric nitrogen deposition increase on net mineralization flux of forest soil nitrogen in a site located in Qinghai-Tibet Plateau forest was conducted over a pefuture atmospheric nitrogen deposition increase. 
riod of two years. This timely research will help to further our current understanding and the extent of the effects of nitrogen deposition on the net mineralization flux of forest soil nitrogen and the effect of climatic factors on the net mineralization flux of forest soil nitrogen.

\section{MATERIALS AND METHODS}

\subsection{The study area}

The study area is located in the comprehensive observation station of the Chinese Academy of Sciences in Nyingchi LuLang town of the Tibet autonomous region $\left(29^{\circ} 46^{\prime} \mathrm{N}, 94^{\circ} 44^{\prime} \mathrm{E}\right)$ of the southeast mountain region. The study area has a flat topography with an elevation of 3200 metres above sea level. The Nyingchi area is a typical tropical humid and semi-humid climate affected by The Indian Ocean and the Pacific warm current. It features a short frost-free period (about 170 days throughout the year) and a long frozen period, dry and windy in spring, short and warm summer, cool and foggy autumn, and long and sunny cold winter. The average annual temperature is $12^{\circ} \mathrm{C}$. The annual average rainfall is $600-800 \mathrm{~mm}$ and $92.4 \%$ of the rainfall occurs in spring.

The vegetation type is coniferous Picea-Abies forest in the Tibetan plateau. The forest type is a mature virgin forest and the dominant tree species are on average more than 100 years old. The main tree species include: Abies georgei var. smithii, Picea likiangenses var. linzhiensis, Pinus yunnanensis and Pinus densata. The soil in this area is a Cambisol.

\subsection{Sample collection and analysis}

Self-made rain collectors were used to gather penetration rainwater. The rainwater collector consists of a funnel and a collection bottle. According to seasonal changes in rainfall intensity, 2-3 random samplings were made in each month. In total, 16 collectors were evenly placed around the experimental area to capture the regional heterogeneity in precipitation rate at the site. The sampling period was from May to October during 2012 and 2013.

The resin core method proposed by BHOGAL et al. (1999) was used for the in-situ measurement of the net ammonification, net nitrification, and net mineralization fluxes of soil nitrogen. Considering the thickness of soil layer A and fine root system distribution in the forest, the organic-layer soil depth and "fulllayer" soil depth were determined as $0-7 \mathrm{~cm}$ and $0-15 \mathrm{~cm}$, respectively. These were used as benchmarks for other observations in order to understand any correlation between soil nitrogen transformation flux and the net fluxes of the soil's surface carbon and nitrogen gases, and also the correlation between soil nitrogen transformation flux and the leaching fluxes of the soil's surface carbon and nitrogen gases.

The field experiments began in July 2012. At first, four sampling points adjacent to each other were selected in each treated quadrat, and two repeated treatments were designed for organic layers and full layers in each sampling points. Then, the surface vegetation was completely cleared off, some PVC pipes $(7.0 \mathrm{~cm}$ in diameter and $7.0 \mathrm{~cm}$ in height for organic layers, $7.0 \mathrm{~cm}$ in diameter and $15.0 \mathrm{~cm}$ in height for full layers) were driven by a hammer into the soil. The pipes then were carefully removed and soil of $2 \mathrm{~cm}$ thick was removed from bottom of the pipes and the remaining soil was then put into the prepared resin bags. Each bag contained 20g of cation-anion exchange resin. Finally, the PVC pipes were buried in the original places. Prior to the experiment, the amount of soil taken from $0-7 \mathrm{~cm}$ layer and $0-15 \mathrm{~cm}$ layer outside the experimental plot was considered as the initial baseline values of soil nitrogen mineralization. Then, the soil was sampled in September and November 2012 and April, July, and November 2013. After every sampling, new pipes were buried in new places in the experiment plot until the end of the experiment in November 2013. All the samples were sieved and kept frozen for later analysis. Plots of $5 \mathrm{~m}^{\prime} 5 \mathrm{~m}$ were arranged into three blocks and fertilizer-N was added as annual single doses of $\left(\mathrm{NH}_{4}\right)_{2} \mathrm{SO}_{4}, \mathrm{NH}_{4} \mathrm{Cl}$ and $\mathrm{KNO}_{3}$ from 2012. The doses are 0 (control), 15 (low N) and 30 (high N) kg N ha-1 $\mathrm{yr}^{-1}$.

\subsection{Statistical analysis}

For the soil samples from two different depths, the net ammonification flux of the soil nitrogen can be calculated as the difference between the $\mathrm{NH}_{4}{ }^{+}-\mathrm{N}$ content in the counterpart soil layers between two adjacent samplings plus the $\mathrm{NH}_{4}{ }^{+}-\mathrm{N}$ content absorbed by the resin. The net nitrification flux of the soil nitrogen is the difference between the $\mathrm{NO}_{3}{ }^{-}-\mathrm{N}$ content in the counterpart soil layers between two adjacent samplings plus the $\mathrm{NO}_{3}{ }^{-}-\mathrm{N}$ content absorbed by the resin. The net mineralization flux of the soil nitrogen is the sum of the net ammonification flux and the net nitrification flux (HATCH et al., 2000). The monthly forest precipitation nitrogen deposition flux during the field observation period was calculated by multiplying the precipitation volume mean concentration and the precipitation amount.

The total dissolved nitrogen (DN) in precipitation was been determined with a TOC/TN analysis meter (Shimadzu TOC$\mathrm{V}_{\mathrm{CSH}} / \mathrm{TN}$ ). Dissolved organic nitrogen (DON) in precipitation was also calculated based on the difference between the total nitrogen content and the content of mineral nitrogen. The content of $\mathrm{NH}_{4}{ }^{+}-\mathrm{N}$ and $\mathrm{NO}_{3}{ }^{-}-\mathrm{N}$ in precipitation, resin, and soil samples was determined by the colorimetric method (KIM, 1995). The unit of nitrogen deposition flux in different forms in precipitation and of flux of mineral nitrogen in resin is $\mathrm{mg} \mathrm{N} \mathrm{m}^{-2}$.

For all the forest soil nitrogen mineralization fluxes, the average values and standard errors were calculated. A one-way ANOVA method in a t-test provided using software SPSS11.5 was employed to compare the morphological differences among the deposition of nitrogen in its different forms $(p<0.05)$. Factor analysis in SPSS-Data Reduction was conducted to investigate the differences in net ammonification, net nitrification, and net mineralization fluxes of forest soil nitrogen in different years and under various conditions of nitrogen application. Stepwise regression analysis in SPSS-Regression was used to analyze the key factors in soil attributes, average annual temperature, and annual precipitation which influence the net mineralization flux of forest soil nitrogen. With reference to the literature and based on SPSS factor analysis, the key factors influencing annual net mineralization flux of regional forest soil nitrogen were investigated. For all the results obtained, average values and standard errors were calculated.

The annual nitrogen deposition is the sum total of every monthly figure. The unit of nitrogen sediment fluxes of different forms are $\mathrm{kg} \mathrm{N} \mathrm{ha}^{-1}$. Regression analysis and correlation coefficients between different forms of nitrogen concentrations in wet sediment and atmospheric temperature or precipitation was conducted by the one-way ANOVA of SPSS.

\section{Results and discussion}

\subsection{Change Law of Nitrogen Wet Sediment}

Atmospheric temperature and precipitation in the growing seasons during 2011 and 2013 are shown in Figure 1. These two climate factors have significant seasonal variation, the highest in 


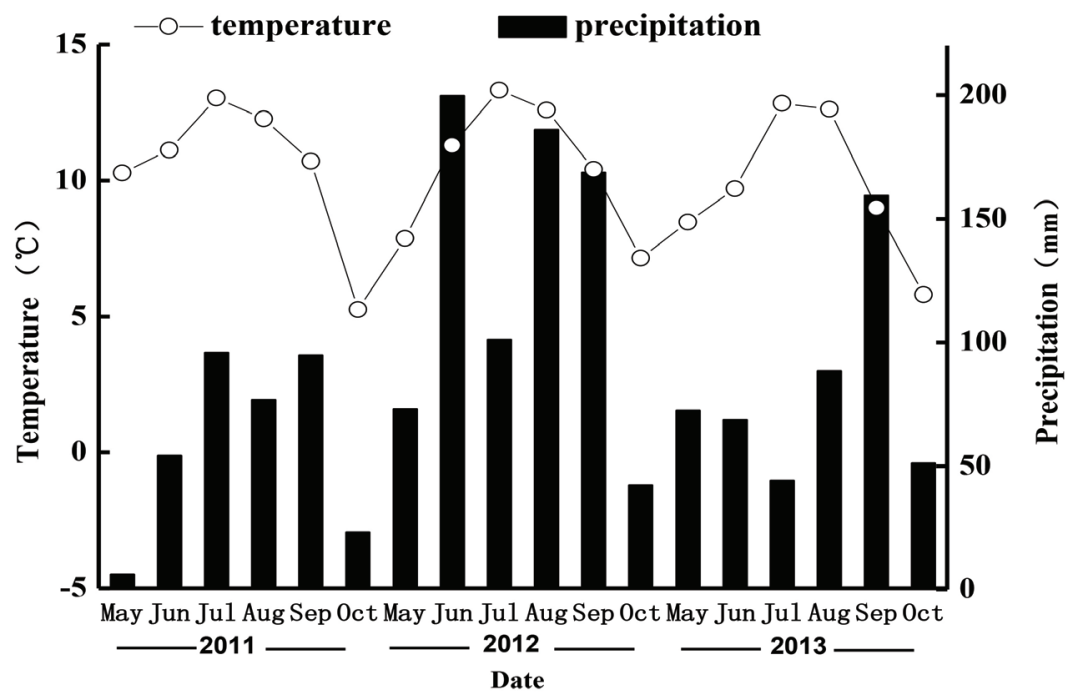

Figure 1. Seasonal changes in atmospheric temperature and precipitation in the forest.

Table 1. Annual changes in different forms of nitrogen content in forest penetration rain.

\begin{tabular}{cccccccc}
\hline & $\mathrm{NH}_{4}{ }^{+}-\mathrm{N}$ & $\mathrm{NO}_{3}{ }^{-}-\mathrm{N}$ & $\mathrm{TIN}$ & $\mathrm{TN}$ & $\mathrm{NH}_{4}{ }^{+}-\mathrm{N} / \mathrm{TIN}$ & $\mathrm{TIN} / \mathrm{TN}$ \\
\hline \multicolumn{5}{c}{$\mathrm{kg} \mathrm{N} \mathrm{ha}{ }^{-1} \mathrm{yr}^{-1}$} \\
\hline 2012 & 5.06 & 2.21 & 6.92 & 8.71 & 73.13 & 79.46 \\
\hline 2013 & 2.93 & 0.44 & 3.38 & 5.58 & 86.83 & 60.48 \\
\hline
\end{tabular}

summer, and the lowest in the spring and autumn. At the same time, there is a big difference in precipitation during each year.

Figure 2. shows different forms of nitrogen $\left(\mathrm{NH}_{4}{ }^{+}-\mathrm{N}, \mathrm{NO}_{3}{ }^{-}\right.$ -N, TIN (Total Inorganic Nitrogen, TIN), TN (Total Nitrogen, $\mathrm{TN})$ ) concentrations in wet sediment flux from May to October in 2012 and 2013. From Figure 1. it can be seen that the atmospheric nitrogen deposition has a significant seasonal change. High values of inorganic $\mathrm{N}$ concentration were found in summer; while, low values were observed in spring.

In 2012, $\mathrm{NH}_{4}{ }^{+}-\mathrm{N}, \mathrm{NO}_{3}{ }^{-}-\mathrm{N}$ and the total mineral nitrogen in the atmospheric wet sediment of coniferous Picea-Abies forest in the Tibetan area were 5.06, 2.21, and $8.71 \mathrm{~kg} \mathrm{~N} \mathrm{ha}^{-1} \mathrm{yr}^{-1}$, respectively. While, the amount of these forms of nitrogen were 2.93,
0.44, and $5.58 \mathrm{~kg} \mathrm{~N} \mathrm{ha}^{-1} \mathrm{yr}^{-1}$ in 2013 (Table 1), respectively. Ammonium nitrogen is the main proportion of the mineral nitrogen sediment which accounts for about $73-87 \%$ of the mineral nitrogen. Mineral nitrogen is the basis of the total nitrogen deposition.

\subsection{The effect of simulated nitrogen deposition on the net transformation flux of soil nitrogen in a temperate forest}

The variation in annual net mineralization flux of soil nitrogen in the control plot in the spruce-fir forest of the Qinghai-Tibet Plateau from 2012 to 2013 was 5.58-8.71 N kg ha-1 $\mathrm{yr}^{-1}$ which is lower than that reported by VESTGARDEN et al. (2003) (-7.7 N $\mathrm{kg} \mathrm{ha}^{-1} \mathrm{yr}^{-1}$ ), BLUMFIELD et al. (2004) (13.4 $\mathrm{N} \mathrm{kg} \mathrm{ha}^{-1} \mathrm{yr}^{-1}$ ) and BRENNER et al. (2005) (13.6-29.7 $\left.\mathrm{N} \mathrm{kg} \mathrm{ha}^{-1} \mathrm{yr}^{-1}\right)$. This is also much lower than the annual net mineralization flux of the soil nitrogen in a European coniferous forest reported by SCHROETER et al. (2003) (30-90 N kg ha-1 $\left.\mathrm{yr}^{-1}\right)$ and the annual net mineralization flux of the soil nitrogen in a Chinese subtropical forest reported by CHEN \& JAN (2007) (62.6 N kg ha-1 $\left.\mathrm{yr}^{-1}\right)$. Clearly, the annual net mineralization flux of forest soil nitrogen may vary

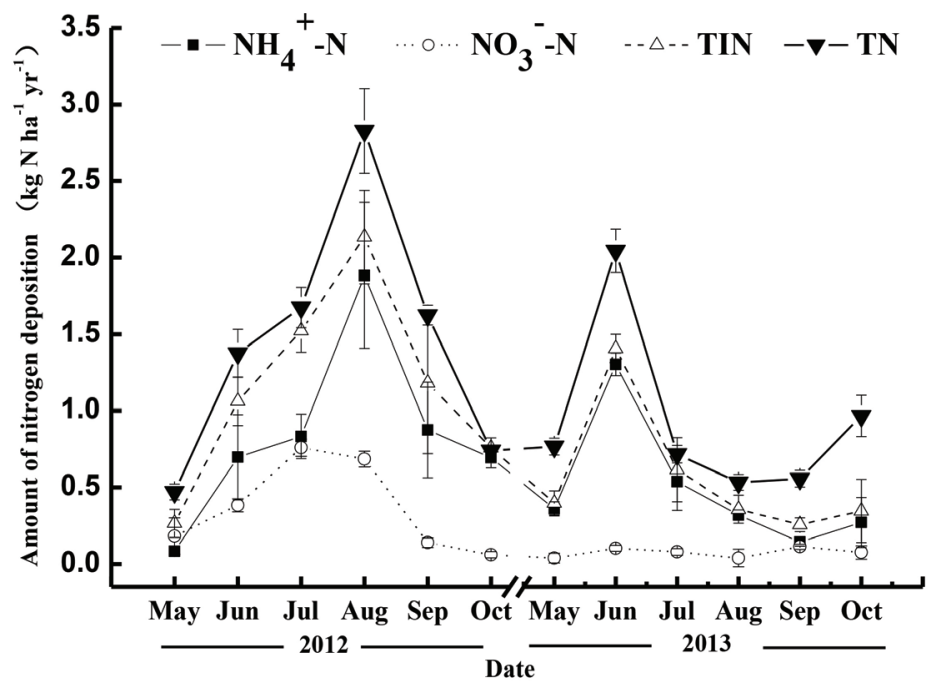

Figure 2. Different forms of nitrogen input in different seasons of Picea-Abies from 2012 to 2013. 

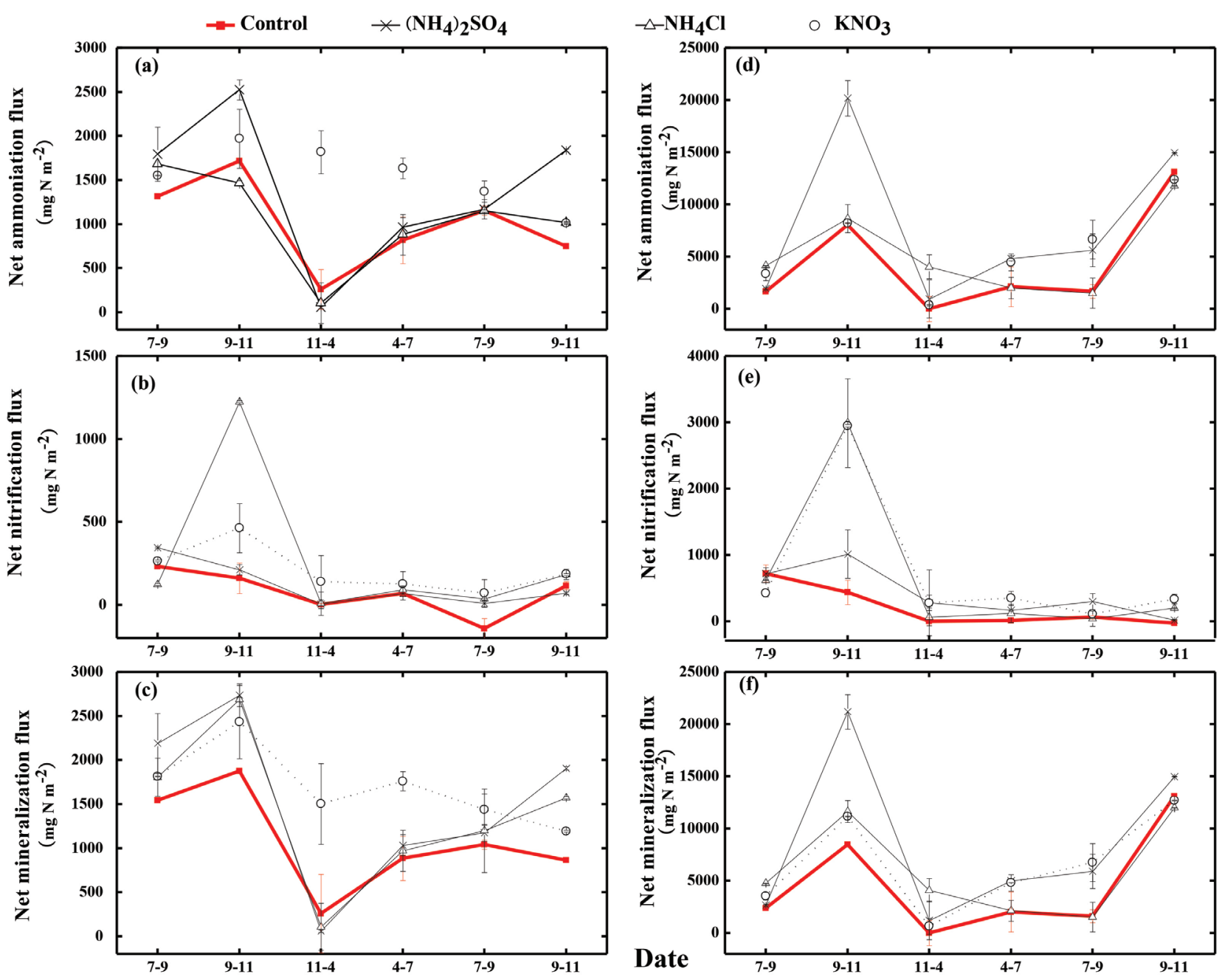

Figure 3. The effect of high nitrogen input on soil net ammonification, net nitrification, and net mineralization in different years. a-c: 0-7cm; $d-f$ : 0-15cm; Error bar is standard error for four repeated measurements.

with different regional atmospheric nitrogen depositions, different soil and forest types, and different experimental methods.

In the field experiment, the control treatment showed that the net ammonification flux, net nitrification flux, and net mineralization flux of the nitrogen in the samples from $0-7 \mathrm{~cm}$ soil layers and $0-15 \mathrm{~cm}$ soil layers share similar seasonal variability. To be more specific, the net transformation flux of nitrogen in summers and autumns of 2012 and 2013 was a little higher than that in the springs and winters of the same years; but, the difference was not significant (Figures 3 and 5). In the experimental plot with no nitrogen, the annual net mineralization fluxes of the nitrogen in the $0-15 \mathrm{~cm}$ soil layers in 2013 were significantly higher than that in $2012(p<0.05)$ (Figure-4 and Figure-6). With linear regression analysis, an equation with two unknowns was established to indicate the influence of temperature $(T)$ and precipitation $(P)$ on the net mineralization flux $\left(Y_{1}\right)$ of the nitrogen in the $0-7 \mathrm{~cm}$ soil layer: $Y_{l}=(3.15 \pm 1.18) T+(5.49 \pm 7.97) P-(82.91 \pm 214.62) .\left(R^{2}=0.94\right.$, $n=6, p<0.05)$ Therefore, according to the regression determination coefficient $\left(R^{2}\right)$, it could be concluded here that the temperature is the key factor influencing seasonal variations in the net transformation flux of forest soil nitrogen (STENGER et al., 1996; PAJUSTE et al., 2003; XU, 2005). KNOEPP \& VOSE (2007) reported that in a mixed broadleaf-conifer forest in the Eastern U.S. the monthly accumulative net mineralization flux and monthly accumulative nitrification flux of temperate forest soil nitrogen increased significantly as the soil temperature and humidity rose. The soil temperature had a greater influence on the net mineralization flux of nitrogen and both the soil temperature and humidity were the reason for $83 \%$ variation in the net mineralization flux of soil nitrogen. PAJUSTE et al. (2003) pointed out that temperature, humidity, and $\mathrm{pH}$ could together explain $70 \%$ of the variation in annual net ammonification flux of the soil nitrogen in a Scots pine (Pinus sylvestris) and Norway spruce forest of East Estonia of which the net ammonification flux of Scots pine (Pinus sylvestris) forest soil nitrogen had a significantly positive correlation with temperature $\left(R^{2}=0.69\right.$, $p<0.0001)$.

The annual net mineralization flux of the fir forest soil nitrogen in Qinghai-Tibet Plateau was mainly manifested by the net ammonification flux which accounts for $76-89 \%$ of the net mineralization flux. In 2013, the input of a high dose of $\mathrm{KNO}_{3}$ significantly inhibited the proportion of net ammonification flux to net mineralization flux of the nitrogen in the $0-7 \mathrm{~cm}$ soil layer. However, the input of $\mathrm{NH}_{4}{ }^{+}-\mathrm{N}$ did not show any significant influence on the proportion of net ammonification flux to net mineralization flux of the nitrogen in the same soil layer. Earlier research suggests that the nitrogen deposition increase was reduced or did not influence the proportion of net ammonification flux to total net mineralization flux of soil nitrogen. BRENNER et al. (2005) reported that the net ammonification flux accounts for $68.9 \%$ of 

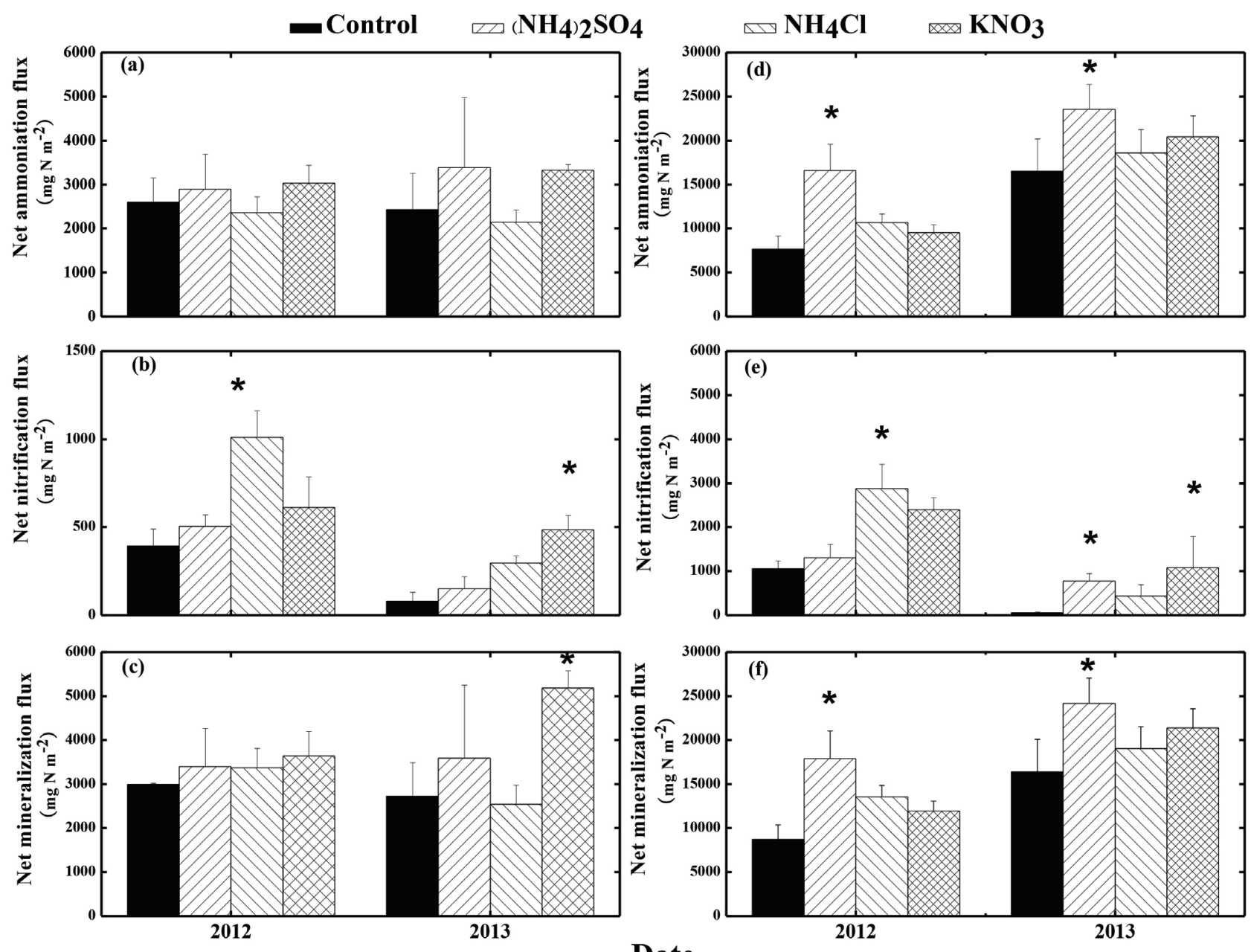

Figure 4. The effect of high nitrogen input on soil net annual nitrogen mineralization in different years. a-c: 0-7cm; $d-f$ : 0-15cm; Error bar is standard error for four repeated measurements. * is significant level with contrast.

the total mineralization flux of the nitrogen in the $0-20 \mathrm{~cm}$ soil layer in a high-latitude forest in the USA and the input of $100 \mathrm{~N}$ $\mathrm{kg} \mathrm{ha}^{-1} \mathrm{yr}^{-1}$ of $\mathrm{NaNO}_{3}$ caused the proportion to decrease to $31 \%$. According to EMMETT et al. (1995), in a forest of the Northern UK, the net ammonification flux accounts for $90 \%$ of the net mineralization flux in the $0-7 \mathrm{~cm}$ soil layer and the input of $35 \mathrm{~N} \mathrm{~kg}$ $\mathrm{ha}^{-1} \mathrm{yr}^{-1}$ of $\mathrm{NH}_{4} \mathrm{NO}_{3}$ and the input of $70 \mathrm{~N} \mathrm{~kg} \mathrm{ha}^{-1} \mathrm{yr}^{-1}$ of $\mathrm{NH}_{4} \mathrm{NO}_{3}$ caused the proportion to decrease to $85 \%$ and $75 \%$, respectively.

At the initial phase of the field experiment, the input of different doses of $\mathrm{NH}_{4}{ }^{+}-\mathrm{N}$ significantly promoted $(p<0.05)$ both the annual net ammonification flux and the annual net mineralization flux of the nitrogen in the $0-7 \mathrm{~cm}$ and the $0-15 \mathrm{~cm}$ soil layers; especially in the $0-15 \mathrm{~cm}$ soil layer. The annual net ammonification flux and annual net mineralization flux of the nitrogen in the $0-7 \mathrm{~cm}$ soil layer in the experiment plot applied with $\mathrm{NO}_{3}{ }^{-}-\mathrm{N}$ showed a tendency to increase with the extension of the years of $\mathrm{NO}_{3}{ }^{-}-\mathrm{N}$ application compared with the application of $\mathrm{NH}_{4}{ }^{+}-\mathrm{N}$ (see Figure-3 and Figure-5). These results suggest that for the same site conditions, the influences from the input of nitrogen in different forms on forest topsoil nitrogen transformation flux might be different. Previous research showed that a short period (e.g., 1 to 2 years) of simulated nitrogen deposition increase significantly promoted the net mineralization flux of forest soil nitrogen (EMMETT et al., 1995; SULTANA et al., 2004; BREN-
NER et al., 2005). The 14-year (from 1988 to 2002) simulated nitrogen deposition experiment conducted by MCNULTY et al. (2005) on a redwood forest of the U.S. showed that the increase of $\mathrm{NH}_{4} \mathrm{Cl}$ input significantly promoted the net mineralization flux of soil nitrogen in the first four years of the experiment. However, the promotion weakened gradually with the extension of the years of $\mathrm{NH}_{4} \mathrm{Cl}$ application. By 1994, the nitrogen mineralization potential of the soil in the plot supplied with nitrogen was lower than that in the control plot and nitrogen deposition increase did not significantly influence the net mineralization flux of the soil nitrogen. It is evident that the increase in nitrogen input, especially $\mathrm{NH}_{4}{ }^{+}$-N input, significantly promotes the net mineralization flux of soil nitrogen in a short period (e.g., from 1 to 3 years). However, the promotion gradually weakens with the extension of the years of nitrogen application.

With the increase in nitrogen deposition, the net mineralization flux of soil nitrogen increases accordingly and the contribution rate of nitrogen deposition to net mineralization flux in the temperate old-growth forest is about 25\%. MAGILL et al. (2000) conducted a nine-year in-situ observation on the net mineralization flux of soil nitrogen in a mixed broadleaf-conifer forest in the eastern part of Maine (USA). Their results showed that both the input of a low dose $\left(50 \mathrm{~N} \mathrm{~kg} \mathrm{ha}^{-1} \mathrm{yr}^{-1}\right)$ and a high dose $(150 \mathrm{~N}$ $\left.\mathrm{kg} \mathrm{ha}^{-1} \mathrm{yr}^{-1}\right)$ of $\mathrm{NH}_{4} \mathrm{NO}_{3}$ significantly promotes the net mineralization flux of soil nitrogen. The promotion by application of the 
㖜

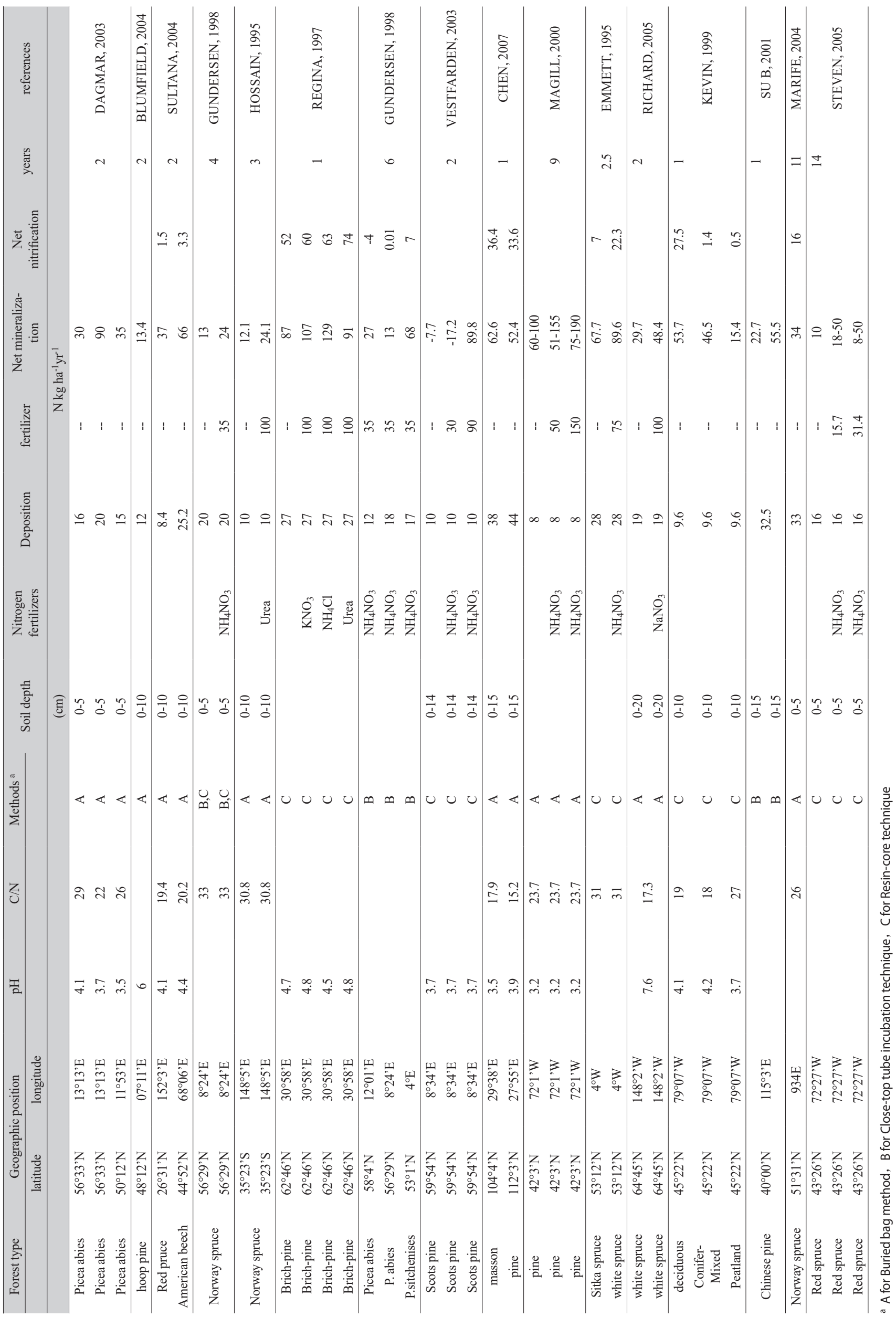



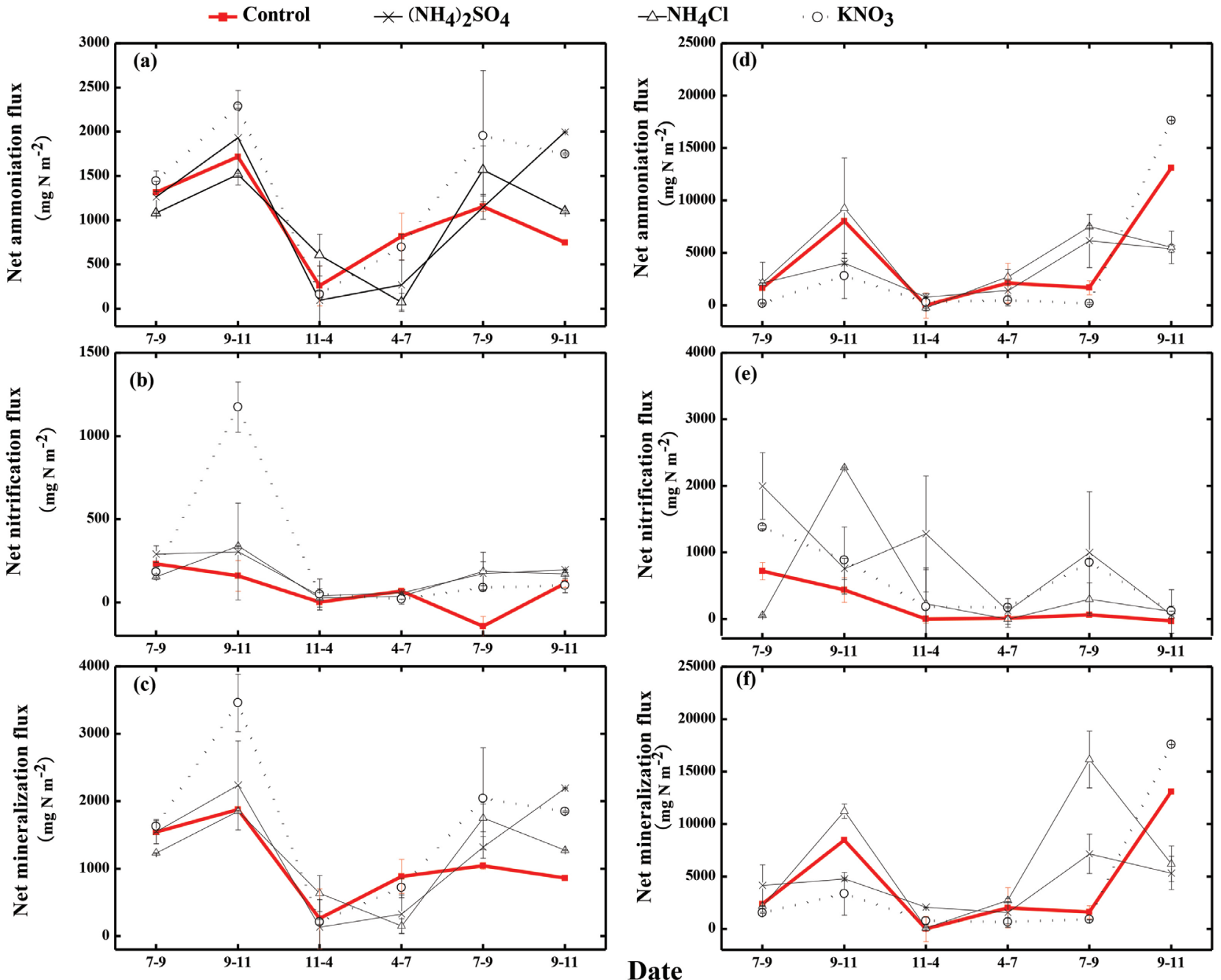

Figure 5. Th effect of low nitrogen input on soil net ammonification, net nitrification, and net mineralization in different years. a-c: 0-7cm; $d$-f: 0 -15 $\mathrm{cm}$; Error bar is standard error for four repeated measurements.

high dose was much more obvious and the contribution rate of exogenous nitrogen input to the net mineralization flux of soil nitrogen was about $64 \%$. VESTGARDEN et al. (2003) reported that $34 \%$ of the net mineralization flux of Scots pine (Pinus sylvestris) forest soil nitrogen in Northern Norway is attributed to exogenous nitrogen application.

Another observed result by MCNULTY et al. (2005) showed that the average contribution rate of nitrogen deposition increased the net mineralization flux of forest soil nitrogen for about $21 \%$ over a 12 year observation period. They also found the contribution rates of nitrogen deposition to the net mineralization flux of the forest soil nitrogen in different areas were significantly different. This may be closely related to forest type, climatic factors (such as annual precipitation and average annual temperature), and soil attributes.

\subsection{Prediction of the effect of simulated nitrogen deposition on the annual net mineralization flux of forest soil nitrogen in different areas}

Until now, both Chinese and international research on the response of soil nitrogen transformation in forest ecosystems to atmospheric nitrogen deposition was mainly conducted in sample plots and communities which were relatively small in scale. The focus of this research was mainly on the investigation of the mechanism of net mineralization flux of soil nitrogen. Investigation of the influence of nitrogen input and its synergistic factors on the net mineralization flux of forest soil nitrogen from the perspective of the regional scale was not addressed properly in the literature. In reality, the net mineralization fluxes of soil nitrogen show great differences in different forest ecosystems due to different vegetation, soil matrix, and climatic factors. Hence, on a global scale, for a deep understanding of global forest soil nitrogen transformation patterns and for a response to global warming, it is extremely essential to establish the law leading to zonal distribution of net mineralization of forest soil nitrogen as well as its influencing factors.

In the section, the results of the current research on the influence of nitrogen deposition increase on main soil carbon and nitrogen processes in regional forest ecosystems is summarized. The correlation between environmental factors such as climatic and biotic factors is discussed in Table 1. The results show that the annual net mineralization flux of forest soil nitrogen significantly increases linearly with the increase in atmospheric nitrogen deposition. In addition, the contribution rate of nitrogen deposition to the annual net mineralization flux of the forest soil nitrogen is about $48 \%$ (Figure 7.). According to CHEN \& JAN (2007), in East China, when the nitrogen deposition was 25-49 N $\mathrm{kg} \mathrm{ha}^{-1} \mathrm{yr}^{-1}$, the net mineralization flux of subtropical forest soil 

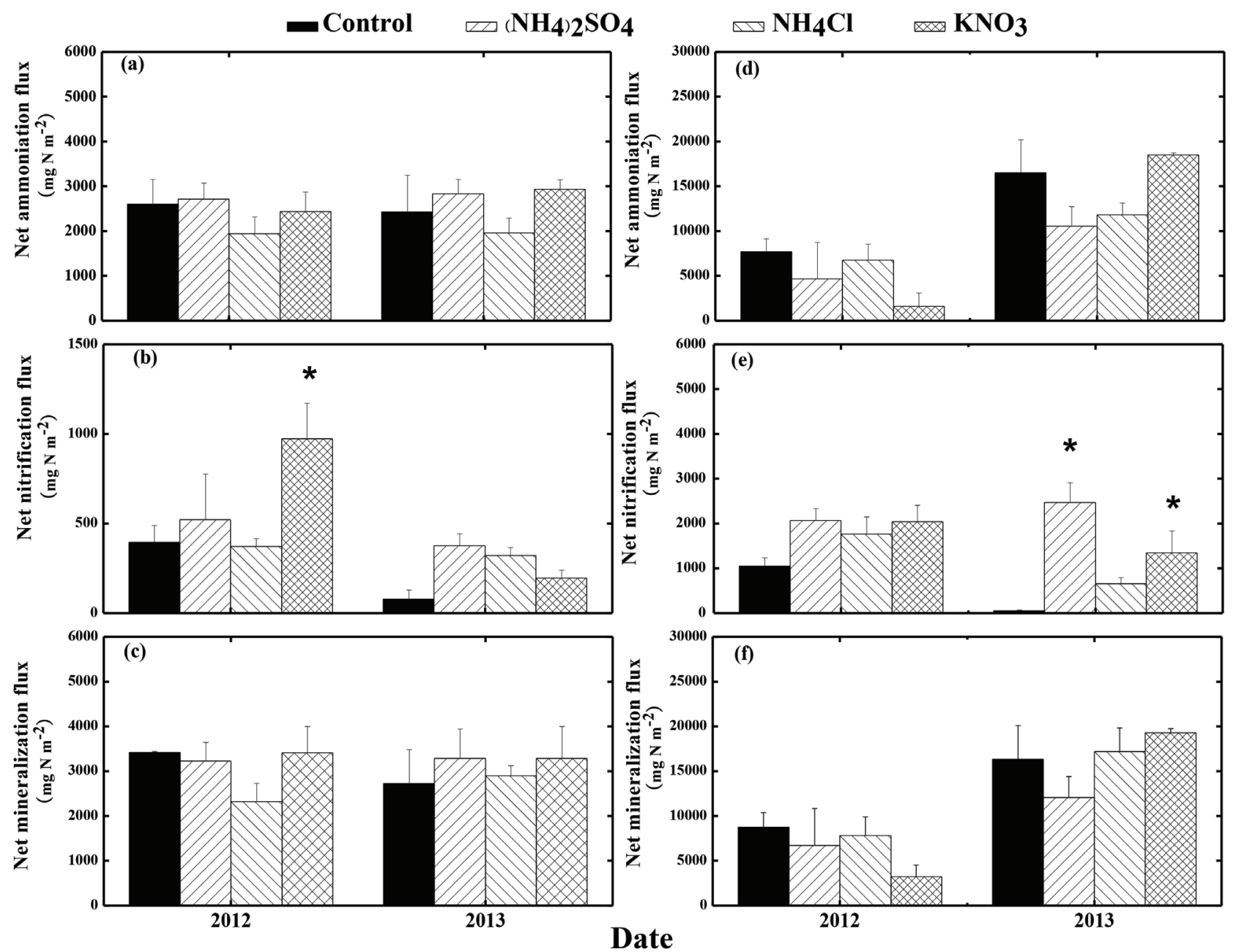

Figure 6. The effect of low nitrogen input on soil net annual nitrogen mineralization in different years. a-c: $0-7 \mathrm{~cm}$; $d$-f: $0-15 \mathrm{~cm}$; Error bar is standard error for four repeated measurements. ${ }^{*}$ is significant level with contrast.

nitrogen was $52-62 \mathrm{~N} \mathrm{~kg} \mathrm{ha}^{-1} \mathrm{yr}^{-1}$, and the contribution rate of nitrogen deposition to the net mineralization flux of soil nitrogen was 34\%. PÉREZ et al. (1998) studied the annual net mineralization flux of temperate old-growth forest soil nitrogen in North America. They reported that the net mineralization flux of Hinoki cypress (Chamaecyparis obtuse) forest soil nitrogen was 20-23 $\mathrm{N} \mathrm{kg} \mathrm{ha-1} \mathrm{yr}^{-1}$, and that of beech forest soil nitrogen was $31-37 \mathrm{~N}$ $\mathrm{kg} \mathrm{ha}^{-1} \mathrm{yr}^{-1}$. A long period of atmospheric nitrogen deposition increase would reduce the carbon-to-nitrogen $(\mathrm{C} / \mathrm{N})$ ratio of the forest soil in the Northern Hemisphere and then the promoted soil nitrogen mineralization flux. Based on GUNDERSEN (1998), when atmospheric nitrogen deposition was 13-59 $\mathrm{N} \mathrm{kg} \mathrm{ha}^{-1} \mathrm{yr}^{1}$, the net mineralization flux of European coniferous forest soil nitrogen increased with the increase in nitrogen deposition. The contribution rate of nitrogen deposition to the net mineralization flux of soil nitrogen was $38 \%$.

\section{CONCLUSION}

Net ammonification accounts for about $76-89 \%$ of the net mineralization; while it decreases to $64-83 \%$ in $\mathrm{KNO}_{3}$ treatments. The net $\mathrm{N}$ mineralization rate increased with nitrogen input, especially in $\mathrm{NH}_{+}{ }_{+}^{-} \mathrm{N}$ treatments $(\mathrm{p}<0.05)$. However, this promoting role decreased over time in longer experiments. At the highest $\left(\mathrm{NH}_{4}\right) 2 \mathrm{SO}_{4}$ addition, the net ammonification and net mineralization rate increased more clearly in the humus $(0-7 \mathrm{~cm})$ than in the

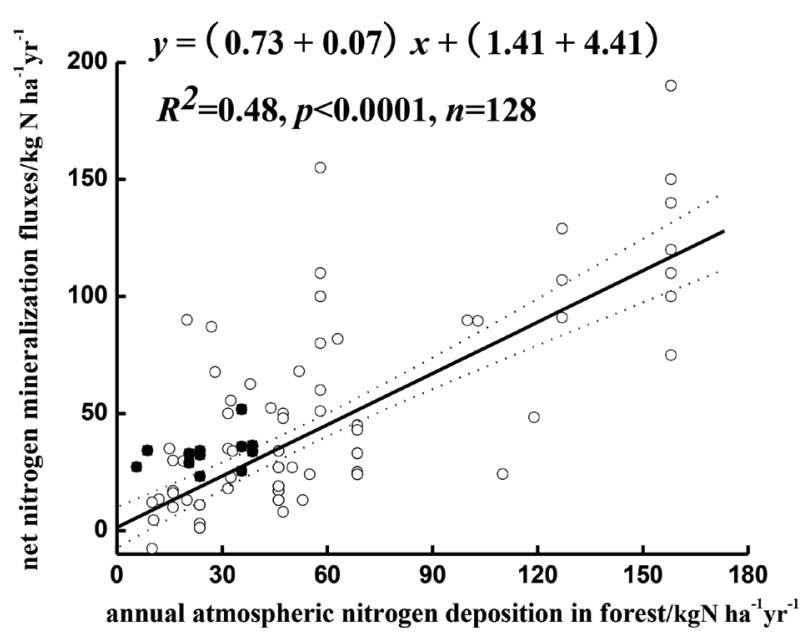

Figure 7. The relationship between net nitrogen mineralization fluxes with annual atmospheric nitrogen deposition in forest ecosystem. Solid circles are data points for the current observations, open circles are data points for previous in situ observational data.

uppermost mineral layer $(0-15 \mathrm{~cm})$. A compilation of previous studies conducted on soil net mineralization from forests under different environmental conditions was evaluated for the effects of atmospheric $\mathrm{N}$ deposition and environmental factors, annual 
precipitation, and annual temperature on annual fluxes of net nitrogen mineralization in forest soils in the global scale. The results showed that increased atmospheric $\mathrm{N}$ deposition significantly enhanced the soil net nitrogen mineralization rate. The variations in atmospheric $\mathrm{N}$ deposition account for $48 \%$ of the variation in rates of soil net nitrogen mineralization across the forests.

\section{ACKNWLEDGEMENT}

Dr. Yongjie Wang, Boqing Xu and Jinlong Chang of the Southeast Mountain Environment Comprehensive observation station of Chinese Academy of Sciences assisted with sample collection and analysis. Thanks also to employees of the Institute of Tibetan Plateau Research Chinese Academy of Sciences for assistance and their cooperation in the experiments.

\section{REFERENCES}

ABER, J.D. \& MAGILL, A.H. (2004): Chronic nitrogen additions at the Harvard Forest: the first 15 years of a nitrogen saturation experiment.- Forest Ecology and Management, 196, 1-5.

ARNOLD, J., CORRE, M.D. \& VELDKAMP, P. (2008): Cold storage and laboratory incubation of intact soil cores do not reflect in-situ nitrogen cycling rates of tropical forest soils.- Soil Biology \& Biochemistry, 40, 2480-2483. doi: 10.1016/j. soilbio.2008.06.001

BHOGAL, A., HATCH, D.J. \& SHEPHERD, M.A. (1999): Comparison of methodologies for field measurement of net nitrogen mineralization in arable soils.- Plant and Soil, 207, 15-28.

BLUMFIELD, T.J., XU, Z.H. \& SAFFIGNA, P.G. (2004): Carbon and nitrogen dynamics under windrowed residues during the establishment phase of a secondrotation hoop pine plantation in subtropical Australia.- Forest Ecology and Management, 200, 279-291.

BRENNER, R.E., BOONE, R.D. \& RUESS, R.W. (2005): Nitrogen additions to pristine, high-latitude, forest ecosystems: consequences for soil nitrogen transformations and retention in mid and late succession.- Biogeochemistry, 72, 257-282. doi: 10.1007/s10533-004-0356-y

BURTON, J., CHEN, C.R., XU, Z. H. \& GHADIRI, H. (2007): Gross nitrogen transformations in adjacent native and plantation forests of subtropical Australia.- Soil Biology \& Biochemistry, 39, 426-433. doi: 10.1016/j.soilbio.2006.08.011

CHEN, X.Y. \& JAN, M. (2007): Indicators for nitrogen status and leaching in subtropical forest ecosystems, South China.- Biogeochemistry, 82, 165-180. doi: 10.1007/ s10533-006-9061-3

CORRE, M.D. \& LAMERSDORF, N.P. (2004): Reversal of nitrogen saturatioin after long-term deposition reduction: impact on soil nitrogen cycling.- Ecology. 85/11, 3090-3140.

DAVID, M. B., CUPPLES, A. M., LAWRENCE, G. B., SHI, G., VOGT, K. \& WARGO, P.M. (1998): Effect of chronic nitrogen additions on soil nitrogen fractious in red spruce stands.- Water, Air, and Soil Pollution, 105, 183-192.

DEVITO, K.J., WESTBROOK, C.J. \& SCHIFF, S.L. (1999): Nitrogen mineralization and nitrigicatioin in upland and peat land of rest soils in two Canadian Shield catchments.- Canadian Journal of Forest Research, 29, 1793-1804.

EMMETT, B.A., BRITTAIN, S.A., HUGHES, S. \& KENNEDY, V. (1995): Nitrogen additions $\left(\mathrm{NaNO}_{3}\right.$ and $\left.\mathrm{NH}_{4} \mathrm{NO}_{3}\right)$ at Aber forest, Wales: II. Response of trees and soil nitrogen transformations.- Forest Ecology and Management, 71, 61-73. doi: 10.1016/0378-1127(94)06084-V

FANG, Y.T., MO, J.M. \& GUNDERSEN, P. (2004): Nitrogen transformations in forest soils and its responses to atmospheric nitrogen deposition: a review.-Acta ecologica sinica, 24/7, 1523-1531.

GUNDERSEN, P. (1998): Effects of enhanced nitrogen deposition in a spruce forest at Klosterhede, Denmark, examined by moderate $\mathrm{NH}_{4} \mathrm{NO}_{3}$ addition.- Forest Ecology and Management, 101, 251-268, doi: 10.1016/S0378-1127(97)00141-2

GUNDERSEN, P., EMMETT, B.A., KJONAAS, O.J., KOOPMANS, C.J. \& TIETEMA, A. (1998): Impact of nitrogen deposition on nitrogen cycling in forests: a synthesis of NITREX data.- Forest Ecology and Management, 101, 37-55. doi: 10.1016/S0378-1127(97)00124-2
HATCH, D. J., BHOGAL, A., LOVELL, R. D., SHEPHERD, M.A. \& JARVIS, S.C. (2000): Comparison of different methodologies for field measurement of net nitrogen mineralization in pasture soils under different soil conditions. - Biology and Fertility of Soils, 32, 287-293. doi: 10.1007/s003740000250

HOSSAIN, A.K.M.A., RAISON, R.J. \& KHANNA, P.K. (1995): Effects of fertilizer application and fire regime on soil microbial biomass carbon and nitrogen, and nitrogen mineralization in an Australian subalpine eucalypt forest.- Biology and Fertility of Soils, 19, 246-252. doi: 10.1007/BF00336167

JUSSY, J.H., BELGRAND, M.C., DAMBRINE, E., RANGER, J., ZELELR, B. \& BIENAIME, S. (2004): N deposition, $\mathrm{N}$ transformation and $\mathrm{N}$ leaching in acid forest soils.-Biogeochemistry, 69, 241-262. doi: 10.1023/B:BIOG.0000031050.13663.82

KIM, H.T. (1995): Soil Sampling, Preparation and Analysis. New York: Marcel Dekker.

KNOEPP, J.D. \& VOSE, J.M. (2007): Regulation of nitrogen mineralization and nitrification in southern Appalachian ecosystems: separating the relative importance of biotic vs. abiotic controls.- Pedobiologia, 51, 89-97. doi: 10.1016/j.pedobi.2007.02.002

LI, M.R. \& SHA, L.Q. (2005): Soil nitrogen mineralization under different land use patterns in Xishuangbanna.- Chinese journal of applied ecology, 16/1, 54-58.

MAGILL, A.H., ABER, J.D., BERNTSON, G.M.,MCDOWELL, H. NADELHOFFER, K.J., MELILLO, J.M. \& STEUDLER, P. (2000): Long-term nitrogen additions and nitrogen saturation in two temperate forests.- Ecosystems, 3, 238-253. doi: $10.1007 / \mathrm{s} 100210000023$

MAGILL, A.H., DOWNS, M.R., NADELHOFFER, K.J., HALLETT, R. \& ABER, J.D. (1996): Forest ecosystem response to four years of chronic nitrate and sulfate additions at Bear Brooks Watershed, Maine, USA.- Forest Ecology and Management. 1996, 84/1-3, 29-37. doi: 10.1016/0378-1127(96)03775-9

MCNUlTy, S.G., BOGGS, J., ABER, J.D., RUSTAD, L. \& MAGILL, A. (2005): Red spruce ecosystem level changes following 14 years of chronic $\mathrm{N}$ fertilization.Forest Ecology and Management, 219, 279-291.

MENG, Y., XUE, J. Y. \& SHA, L. Q. (2001): Variations of soil $\mathrm{NH}_{4}{ }^{+}-\mathrm{N}, \mathrm{NO}_{3}{ }^{-}-\mathrm{N}$ and mineralization under different forests in Xishuangbanna, southwest China.-Acta phytoecologica sinica, 25/1, 99-104.

OUYANG, X. J., ZHOW, G. Y. \& HUANG, Z. L. (2008): Effect of simulated acid rain on potential carbon and nitrogen mineralization in forest soils.- Pedosphere, 18/4, 503-514.

PAJUSTE, K. \& FREY, J. (2003): Nitrogen mineralization in podzol soils under boreal Scots pine and Norway spruce stands.- Plant and soil, 257, 237-247.

PÉREZ, C.A., HEDIN, L.O. \& ARMESTO, J.J. (1998): Nitrogen mineralization in two unpolluted old-growth forests of contrasting biodiversity and dynamics.-Ecosystems, 361-373.

REGINA, K., NYKANEN, H., MALJANEN, M., SILVOLA, J. \& MARTIKAINEN, P. J. (1997): Emission of $\mathrm{N}_{2} \mathrm{O}$ and $\mathrm{NO}$ and net nitrogen mineralization in a boreal forested peatland treated with different nitrogen compounds.- Can. J. For. Res., 28, 132-140.

RICHTER, A., BURROWS, J.B., NÜSS, H, GRANIER, C. \& NIEMEIER, U. (2005): Increase in tropospheric nitrogen dioxide over China observed from space.- Nature, 437, 129-132.

SCHROETER, D., WOLTERS, V. \& DE RUITER, P.C. (2003): N mineralization in the decomposer food webs of a European forest transect.- Oikos, 102, 294-308.

STENGER, R., PRIESACK, E. \& BEESE, F. (1996): In situ studies of soil mineral N fluxes: some comments on the applicability of the sequential soil coring method in arable soils.- Plant and soil, 183, 199-211.

SU, B., HAN, X.G. \& QU, C.M. (2001): Net nitrogen mineralization and nitrification in one pure pine forest and one pine-oak mixed forest in dongiling mountainous region.- Acta Phytoecologica Sinica, 25/2, 195-203.

SULTANA, J., FERNANDEZ, I.J., LINDSEY, E.R. \& DAIL, B. (2004): Decadal responses in soil N dynamics at the Bear Brook Watershed in Maine, USA.-Forest Ecology and Management, 189, 189-205.

VESTGARDEN, L.S., SELLE, L.T. \& STUANES, A.O. (2003): In situ soil nitrogen mineralization in a Scots pine (Pinus sylvestris L.) Stand: effects of increased nitrogen input.- Forest Ecology and Management, 176, 205-216.

XU, Z. Z. \& ZHOU, G. S. (2005): Effects of water stress on photosynthesis and nitrogen metabolism in vegetative and reproductive shoots of Leymus Chinensis.-Photosynthetica, 43, 29-35.

ZHOU, C.P. \& OUYANG, H. (2001): Effects of temperature on nitrogen mineralization at optimum and saturated soil water content in two types of forest in Changbai Mountain.-Acta Ecologica Sinica, 21/9, 1469-1473.

ZHOU, C.P., OUYANG, H. \& PEI, Z.Y. (2003): Net soil nitrogen mineralization in Chinese forest ecosystems.- Acta Phytoecologica Sinica, 27/2, 170-176. 